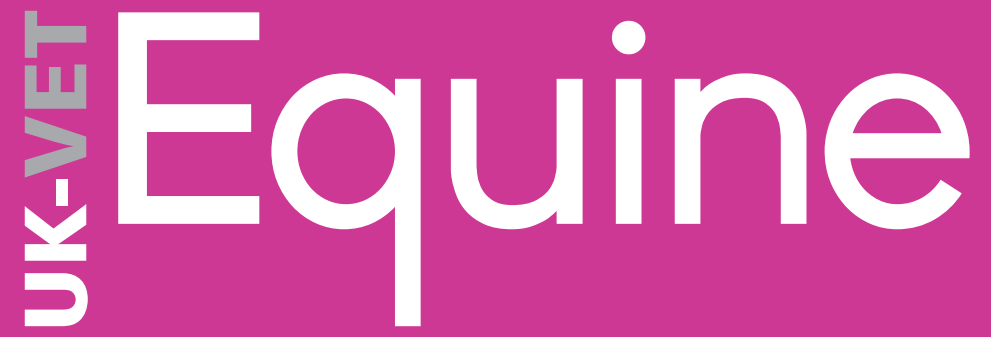

\title{
Equine herpesviruses: a roundtable discussion
}
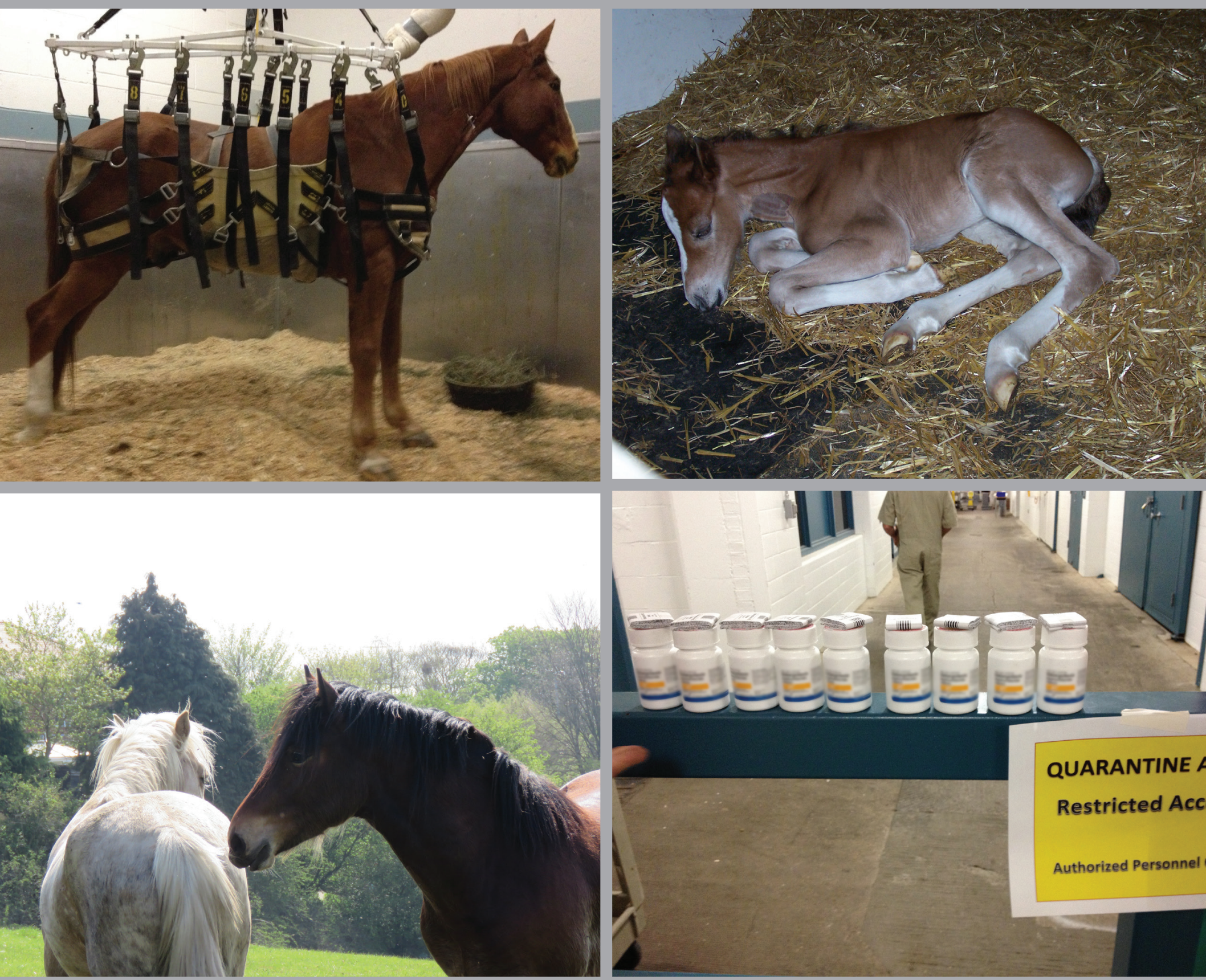
The Panel:

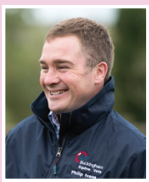

Philip IvensMA VetMB CertEM(IntMed) DipECEIM MRCVS. EBVS European Veterinary Specialist in Equine Internal Medicine \& RCVS Specialist In Equine Medicine (Internal Medicine) Philip co-founded Buckingham Equine Vets in 2011, and has spent the subsequent years developing the practice to meet the needs of local clients. He worked initially in mixed practices in Norfolk and Dorset, then undertook an equine internal medicine residency at the Equine Referral Hospital at the Royal Veterinary College in London. He also runs Buckingham Equine Medicine Referrals to provide specialist expertise to complex medicine cases both locally and far afield. Philip's particularly interests are equine infectious diseases, gastroscopy, sarcoid removal and ophthalmology. He regularly lectures on these conditions and more throughout the UK and is a regular contributor to the equine press, veterinary magazines and scientific publications.

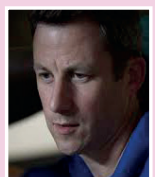

David Rendle BVSC MVM CertEM(IntMed) DipECEIM MRCVS

David is a director at Rainbow Equine Hospital, North Yorkshire, and splits his time between leading the internal medicine and critical care services and running the referral laboratory. Since graduating from The University of Bristol in 2001 he has worked in universities in both the UK and Australia but has spent most of his career in private equine practice in the UK. He is actively involved in all fields of equine medicine and has published on a range of topics, but has particular interests in endocrinology, gastroenterology and respiratory disease. He holds the RCVS certificate in equine medicine and was awarded a masters degree from The University of Glasgow.

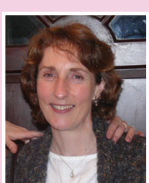

\section{Julia Kydd BSc MSc PhD} PGCHE

Julia Kydd has a BSc (Hons) in Zoology from Dundee University, an MSc in Equine Studies (Aberystwyth University) and $\mathrm{PhD}$ in the mare's immune response to pregnancy (Cambridge University). After 10 years working with Prof WR (Twink) Allen at the Equine Fertility Unit, she moved to undertake scientific research on immunity to equine herpesvirus-1 at the Equine Virology Unit, Animal Health Trust, Newmarket under the leadership of Profs Jenny Mumford and Duncan Hannant. Julia joined the School of Veterinary Medicine and Science in 2006 as a lecturer and Senior Tutor. She is also a Senior Fellow of the Higher Education Academy. Julia is a member of the International Equine Infectious Disease Symposium Committee, has co-organised several international workshops on Equine
Herpesvirus-1 and currently undertakes research into equine hepacivirus.

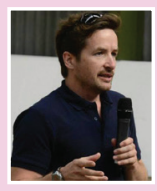

\section{James Crabtree BVM\&S}

CertEM(StudMed) MRCVS James is director of Equine Reproductive Services (UK) Limited, a busy first opinion and referral equine practice in Yorkshire. James graduated from the Royal (Dick) School of Veterinary Studies, Edinburgh in 2001. James spent 4 years in mixed practice in Yorkshire, then in 2004 embarked on a journey that saw him perform multiple back to back breeding seasons in the Southern and Northern hemispheres working with specialists in the UK, Australia and New Zealand. During his time at home in Yorkshire he worked with Dr Jonathan Pycock. In 2010 James was awarded the RCVS certificate in Equine Stud Medicine and in 2011 was made an associate lecturer at Liverpool University. He lectures regularly nationally and internationally and has published on many topics including infectious diseases (equine viral arteritis), the breeding soundness examination of the stallion, peri-partum problems in mares, granulosa cell tumours of mares' ovaries, persistent endometrial cups and conditions in foals.

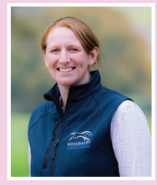

Sarah Moore BVetMed CertAVP(ESM) MRCVS

Sarah qualified from the Royal Veterinary College in 2009 and joined Rossdales, Hertfordshire, in 2013 after spending time in farm and equine practice in Norfolk and Northamptonshire. She has developed a keen interest in stud farm work, and in 2016 was awarded the Certificate in Advanced Veterinary Practice in Equine Stud Medicine. She is currently enrolled on an alternative route residency with the American College of Theriogenology, studying towards the diploma. She sees a large number of Thoroughbred and sports horse breeding clients in the Hertfordshire area, and has an interest in youngstock and bloodstock sales work.

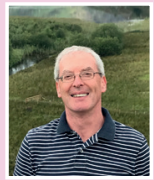

Huw Neal MA VetMB MRCVS Huw Neal qualified from the University of Cambridge in 1983. He first worked in Thirsk and then joined Newmarket Equine Hospital in 1984, where he is currently responsible for commercial and private thoroughbred stud farms. Fetal sex diagnosis has formed a routine part of this service since 1995.

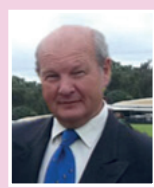

\section{Simon Knapp LVO BSc BVetMed} MRCVS

Simon Knapp qualified from the Royal Veterinary College in 1980 and has worked in genera equine practice ever since, with particular interests in surgery, lameness and poor performance evaluation. After a long stint as Clinical Director for an established equine practice Simon started a new venture this year as the head of Berkshire Equine Limited, a new first opinion practice associated with Newmarket Equine Hospital. Simon is actively involved in the racing world, and attends meetings regularly in his role as Senior Veterinary Surgeon of Kempton Park, Sandown Park and Epsom Downs racecourses, as well as a member of the veterinary team at Ascot Racecourse. $\mathrm{He}$ is also the longest-serving member of the British Horseracing Authority Welfare Committee in his role as Racecourse Association Veterinary Advisor.

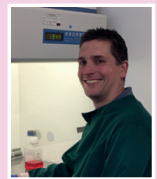

Neil Bryant BSc, PhD

Neil gained his $\mathrm{PhD}$ from the $\mathrm{Di}$ vision of Virology at the University of Cambridge working on immune evasion mechanisms of large DNA viruses; he then moved to the Department of Biochemistry, working with insect and mammalian protein expression systems. He joined the Animal Health Trust as a Postdoctoral Research Associate working on the HBLB sponsored Equine influenza surveillance programme. He is now team leader on the Animal Health Trust's EHV-1 research programme, aiming to develop more efficacious EHV-1 vaccines to protect against the serious consequences of infection: abortion, neonatal foal death and neurological disease. Neil's current interests include virus evolution, herpes virus pathogenicity, viral immune evasion mechanisms, vaccine development and establishing in vitro methods for replacement of experimental work in animals.

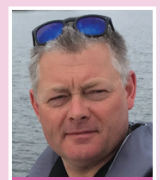

J Richard Newton BVSC MSC PhD FRCVS

After graduating in Veterinary Science from Liverpool University in 1991 and working in mixed veterinary practice, Richard joined the Epidemiology Unit of the Animal Health Trust in 1994. Since completing a Masters in Communicable Disease Epidemiology at the London School of Hygiene and Tropical Medicine in November 1998 he has worked on the epidemiology of a variety of diseases of companion animals, including grass sickness, EIPH and strangles in horses, and influenza, including cross-species transmission from horses to dogs. He completed his PhD on the epidemiology of equine infectious respiratory disease in 2002 and in 2003 was awarded the Diploma of Fellowship from the RCVS. He is currently an Executive Committee member and Director of Epidemiology and Disease Surveillance at the AHT. His group at the AHT has programmes on infectious disease surveillance in the UK for which it prepares quarterly disease reports for Defra and regular updates on global equine disease occurrence through the International Collating Centre. He also oversees research programmes on grass sickness surveillance and vaccination, epidemiological research of equine laminitis and development of a nationwide surveillance scheme for equine strangles. 


\section{Foreword}

There are nine different equid herpesviruses (EHVs). Five types (EHV-1 to EHV-5) infect the domestic horse, while EHV-6 to EHV-9 are associated with infections in wild equids including asses and zebra. This review focuses on the commonest and most important clinical pathogens, the alphaherpesviruses EHV-1 and 4. These are respiratory pathogens and are also responsible for abortion and neurological disease. Several aspects of the biology of these viruses makes their control challenging. In particular, latent infection and reactivation of infection under stress, with subsequent virus shedding, makes elimination of these viruses impossible. Biosecurity measures are important both for minimising the risk of an outbreak and for controlling any outbreak when it occurs. Recognition of the disease and confirmatory diagnosis are also important in order for appropriate biosecurity measures to be instigated. Vaccination in key demographic groups is also important to reduce severe clinical disease. Unfortunately many horse owners are unaware of EHV or the importance of biosecurity measures and vaccination for control.

Ivens P, Rendle D, Kydd J, Crabtree J, Moore S, Neal H, Knapp S, Bryant N, Newton JR

https://doi.org/10.12968/ukve.2019.3.S2.1

Published by: MA Healthcare Ltd, St Jude's Church, Dulwich Road, London SE24 OPB, UK Tel: +44 (0)20 77385454 Web: www.markallengroup.com

Publisher: Chloe Benson Editor: Debra Bourne Design: Fonthill Creative

Cover images: Dr Philip Ivens (top left and bottom right) and Dr Debra Bourne (top right and bottom left)

(c) 2019 MA Healthcare Ltd

All rights reserved. No reproduction, transmission or copying of this publication is allowed without written permission. No part of this publication may be reproduced, stored in a retrieval system, or transmitted in any form or by any means, mechanical, electronic, photocopying, recording, or otherwise, without the prior written permission of MA Healthcare Ltd or in accordance with the relevant copyright legislation. Although the editor and MA Healthcare Ltd have taken great care to ensure accuracy, MA Healthcare Ltd will not be liable for any errors of omission or inaccuracies in this publication.

This article was distributed in UK-Vet Equine | Volume 3 No 4 | July/August 2019

www.magsubscriptions.com/uk-vet-equine 


\section{Equine herpesviruses: a roundtable discussion}

T here are nine different equid herpesviruses (EHVs). Five types (EHV-1 to EHV-5) infect the domestic horse, while EHV-6 to EHV-9 are associated with infections in wild equids, including asses and zebra. The alphaherpesviruses EHV-1 and EHV-4 are respiratory pathogens and are also responsible for abortion and neurological disease. EHV-3 is a venereal pathogen causing coital exanthema and will not be discussed in this article. The gammaherpesviruses EHV-2 and EHV-5 have been associated with ocular and respiratory disease, but their significance has not been fully determined and discussion is beyond the scope of this article. This review focuses on the commonest and most important clinical pathogens, EHV-1 and EHV-4, and outlines their biology; this will demonstrate the challenges of control and the importance of vaccination in key demographic groups.

A recent online survey of more than 1000 horse owners identified a striking lack of awareness of the risks of EHV to their horse, and of the importance of biosecurity measures, in combination with vaccination, to prevent and control the disease (Data on File, Equine Herpes Virus Horse Owner Survey March 2019, Zoetis Inc). Encouragingly, a majority stated they would vaccinate based on veterinary advice.

\section{Prevalence and economic importance of EHV-1 and EHV-4 in the UK}

EHV-1 and 4 are highly host-adapted and successful equine pathogens. Antigenically, they are closely related and develop cross-reactive antibody responses. Their sophisticated life cycle ensures their spread and persistence within the global horse population. There is early and widespread infection of young stock, which combined with widespread latency and reactivation throughout life ensures endemic infection cycles with silent transmission. Spread and persistence of the virus is not dependent on clinical disease, thus ensuring transmission down the generations. (Allen, 2002).

\section{Different disease syndromes}

EHV-1 and 4 are infectious respiratory pathogens. EHV-1 is associated with four clinical disease syndromes (Table 1).

Many factors influence the severity of disease following EHV-1 infection, including virulence of the virus strain (which varies markedly), host immunological status and challenge dose, amongst others. Neuropathogenic and non-neuropathogenic virus strains have been described; however, both strains can cause equine herpes- virus myeloencephalopathy (EHM) and the differentiation is not useful clinically (Lunn et al, 2009). EHV-4 is principally a cause of respiratory disease, although rare, highly virulent endotheliotropic and thus abortigenic strains exist.

Disease outbreaks occur sporadically and the recent UK data is shown in Table 2 (data courtesy of Dr F Whitlock, Animal Health Trust (AHT), Newmarket). The occurrence of disease is likely to under-reported, due to cases going undiagnosed.

\begin{tabular}{|c|c|c|}
\hline Syndrome & Clinical signs of disease & $\begin{array}{l}\text { Common infectious or } \\
\text { non-infectious differential } \\
\text { diagnoses }\end{array}$ \\
\hline Respiratory & $\begin{array}{l}\text { Inapparent or mild but potentially clinically } \\
\text { significant acute disease in older primed } \\
\text { animals } \\
\text { More severe disease of longer duration } \\
\text { in young, immunologically naive animals } \\
\text { Cough is occasional } \\
\text { Serous nasal discharge or mucopurulent } \\
\text { discharge if secondary bacterial infection }\end{array}$ & $\begin{array}{l}\text { EHV-4 } \\
\text { Equine influenza virus (EIV) } \\
\text { Equine viral arteritis (EVA) } \\
\text { Equine rhinitis virus (ERV) } \\
\text { Streptococcus equi ssp. zooepi- } \\
\text { demicus and equi } \\
\text { Inflammatory airway disease }\end{array}$ \\
\hline Abortion & $\begin{array}{l}\text { Usually in pregnant mares beyond } 5 \text { months } \\
\text { of gestation (last trimester) } \\
\text { Typically 'red bag' presentation } \\
\text { No warning signs }\end{array}$ & $\begin{array}{l}\text { Umbilical cord torsion } \\
\text { Bacterial/fungal placentitis } \\
\text { Stillbirth/dystocia } \\
\text { Leptospirosis } \\
\text { Twinning } \\
\text { Body pregnancy }\end{array}$ \\
\hline $\begin{array}{l}\text { Neonatal foal } \\
\text { death }\end{array}$ & Very weak, 'ragdoll', sleepy foal & $\begin{array}{l}\text { Septicaemia secondary to failure } \\
\text { of passive transfer } \\
\text { Neonatal isoerythrolysis }\end{array}$ \\
\hline $\begin{array}{l}\text { Neurological } \\
\text { disease (equine } \\
\text { herpesvirus } \\
\text { myeloencepha- } \\
\text { lopathy (EHM)) }\end{array}$ & $\begin{array}{l}\text { Ranges from mild hindlimb ataxia to quad- } \\
\text { raplegia }\end{array}$ & $\begin{array}{l}\text { Cervical verterbral malformation } \\
\text { Cauda equina syndrome } \\
\text { Polyneuritis equi } \\
\text { Trauma } \\
\text { Orthopaedic issues }\end{array}$ \\
\hline
\end{tabular}

Table 2. Numbers of confirmed UK outbreaks of disease syndromes associated with EHV-1 and EHV-4 infections in 2017 and 2018

\begin{tabular}{|l|l|l|l|}
\hline Year & $\begin{array}{l}\text { Respiratory } \\
\text { Disease }\end{array}$ & Abortion & EHM \\
\hline 2018 - EHV-1 & 3 & 11 & 2 \\
\hline 2018 - EHV-4 & 14 & 1 & 0 \\
\hline 2017 - EHV-1 & 9 & 7 & 3 \\
\hline 2017 - EHV-4 & 4 & 1 & 0 \\
\hline \multicolumn{2}{|l|}{ Data from Animal Health Trust, Newmarket. EHM: equine herpesvirus myeloencephalopathy } \\
\hline
\end{tabular}




\section{Economic importance}

The direct economic impact of EHV-1 infection is hard to enumerate,;however, in the large Thoroughbred and sports horse breeding centres around the world, EHV abortion storms are economically significant (Allen et al, 1999). Fortunately, routine vaccination of pregnant mares and other horses on studs, modern biosecurity systems and improved stud farm management have reduced the prevalence of abortion storms. However, the threat does not diminish, therefore continued implementation of these measures is vital (McCartan et al, 1995).

EHM is potential fatal and mortality rates can be high (Pusterla and Hussey, 2014). Due to the sporadic and unpredictable nature of this disease; the potential for most horses to be latent carriers; and our lack of understanding of reactivation and/or silent viral transmission, all horses remain vulnerable to disease, regardless of their economic value. EHM outbreaks have also necessitated the closure of some equine hospitals, with associated economic consequences. Veterinary surgeons and horse-owners alike have a responsibility to take every precaution and thus keep the prevalence of EHV-related disease as low as possible, although it is not possible to reduce this to zero risk.

\section{Pathogenesis of EHV infection}

EHV-1 typically causes a biphasic pyrexia, however the pyrexia may only have a single phase (Figure 1). Pyrexia may be the only clinical sign and is often missed unless routine monitoring is undertaken. Abortion occurs any time from the second week after infection, and has been reported up to 120 days post-infection (Mumford et al, 1987).

Virus rapidly enters respiratory epithelial cells and is trafficked through the submucosal tissues by direct intracellular transfer to monocytes and lymphocytes. These cells move to local blood vessels and respiratory tract lymph nodes within 12 hours of infection. Virus amplification may occur within the lymph nodes. Infected lymphocytes and monocytes enter the lymphatics and systemic blood circulation, thus establishing a cell-associated viraemia, which disseminates infectious virus to sites of secondary replication including the endothelium of small blood vessels within the placenta and spinal cord; this secondary viral replication event coincides with the second phase of pyrexia. Endothelial cell infection results in a vasculitis and thrombus formation. Within the placenta or spinal cord this reaction may inter-

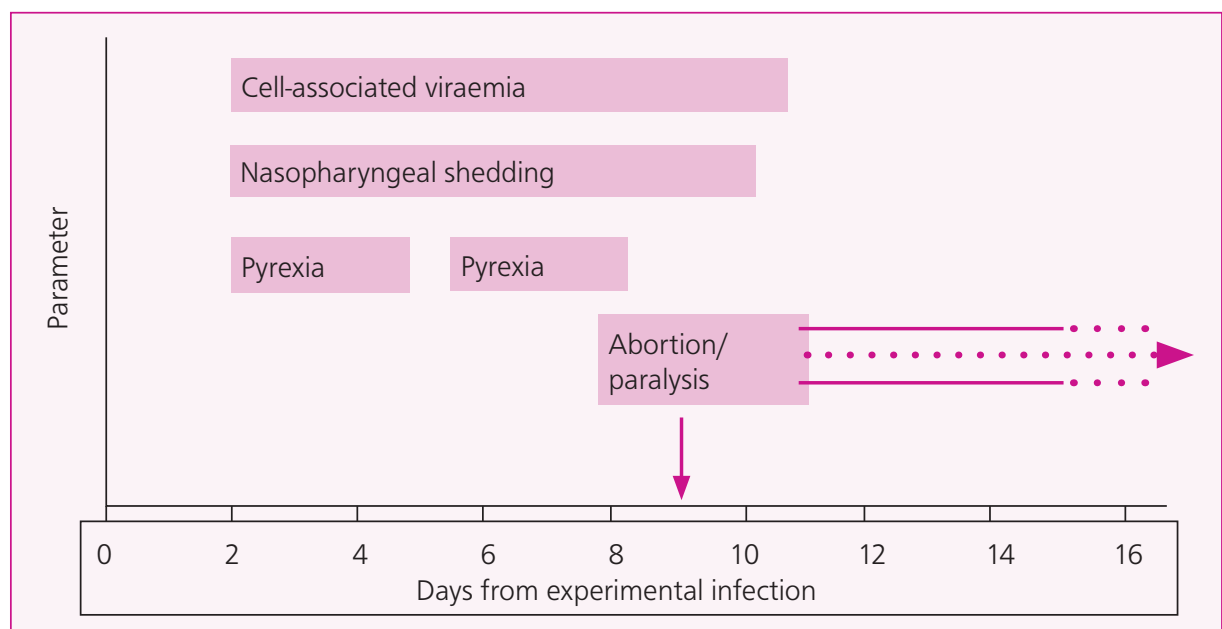

Figure 1. Schematic outlining the approximate timeline of clinical signs, virus shedding and cellassociated viraemia following experimental infection of ponies on day 0 (courtesy of Dr Julia Kydd).

rupt the blood supply to these sensitive tissues, resulting in ischemia and cell death. The equine microcotyledon is very susceptible to thrombus formation as it is supplied by a single arteriole and venule. The simple epitheliochorial equine placenta 'unzips', resulting in rapid expulsion of the intact fetoplacental unit and the characteristic sudden 'red-bag' abortion (Figure 2). Damage to the placenta typically results in EHV infecting the fetus, hence the virus-positive fetal liver, lung and thymus that are often detected post mortem. In EHM, compromise of the spinal blood supply results in swelling of neurons and haemorrhage, with the extent and location of the neurological lesions determining the nature and severity of clinical signs (Table 3 ). The spinal outflow to the caudal and sacral plexus is affected most often (Henninger et al, 2007; Goehring et al, 2010; Burgess et al, 2012).

Factors that may influence the pathogenesis of EHV-1

Factors that affect the severity of clinical signs include virulence of the virus strain; infectious

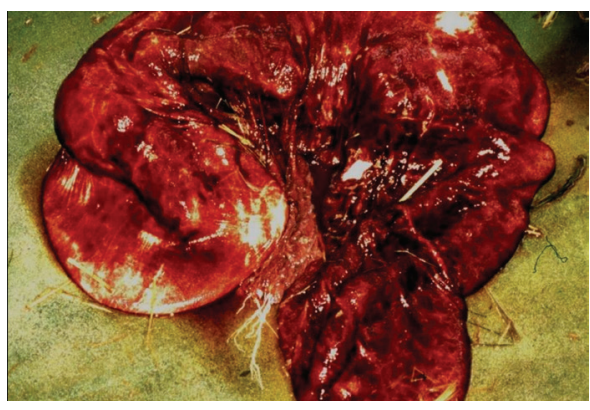

Figure 2. Typical 'red bag' presentation of the abortus in EHV infection. (Image courtesy of Prof Ken Smith, RVC)

dose; level of cell-associated viraemia; degree of ischaemia and consequent pathology; host immunity; and vaccination status (Lunn et al 2009). In addition, some strains of EHV-1 cause immunosuppression in vitro and may compromise immune responses in vivo. However, the importance of this phenomena in vivo is unknown (Ma et al, 2013). Recently, genetic studies on horses affected by EHM have identified a single nucleotide polymorphism in a platelet-related gene (Brosnahan et al, 2019),

\section{Table 3. Clinical signs that may develop in association with EHM}

\begin{tabular}{|l|l|l|}
\hline Anatomical area & Clinical sign & Notes \\
\hline Pelvic limbs & $\begin{array}{l}\text { Temporary ataxia and paresis } \\
\text { which may or may not } \\
\text { progress to quadraplegia }\end{array}$ & $\begin{array}{l}\text { Dragging toes of hind limbs } \\
\text { when moving on a figure } \\
\text { of eight } \\
\text { Hindlimb incoordination } \\
\text { (appears drunk) }\end{array}$ \\
\hline Bladder dysfunction & $\begin{array}{l}\text { Atony with incontinence } \\
\text { and/or urinary retention }\end{array}$ & $\begin{array}{l}\text { Caused by sacral nerve } \\
\text { involvement }\end{array}$ \\
\hline $\begin{array}{l}\text { Cutaneous perineum } \\
\text { and limbs }\end{array}$ & Sensory defects & Rare signs with EHM \\
\hline Cranial nerve signs & Head tilt/facial twitching &
\end{tabular}


which may improve understanding and study of why a subset of horses appear susceptible to this form of disease. One early report postulated that immune complexes between antigen and antibody may influence the development of EHM (Edington et al, 1986), and although vaccination within 5 weeks of exposure has been reported as a risk factor, the association between immune priming and severity of disease remains speculative (Traub-Dargatz et al, 2013).

\section{Requirements to prevent and/or control EHV-1 infection}

Like herpesviruses in other species, control of EHV-1 infection is difficult. Currently, it is generally agreed that control of EHV-1 should focus on prevention of infection of the respiratory epithelium. However, intracellular translocation is rapid and the window of opportunity is short and likely to rely on the presence of pre-existing mucosal antibody. Additional aims are limiting or even preventing the cell-associated viraemia and consequent infection of endothelial cells. A continuing challenge for researchers is to characterise the difference between clinical disease and pathogenesis following intranasal infection compared with reactivation of latent virus.

\section{Diagnosis of EHV infection}

EHV-1 and EHV-4 infection in a fetus or horse may be confirmed by detecting the presence of viral DNA and/or infectious virus, characteristic histopathological changes in fetal tissues, or by demonstrating recent exposure of the host through the presence of elevated titres of anti-EHV-1 or EHV-4 antibodies.

History and clinical signs: EHV-1 infection often occurs in the absence of clinically-apparent respiratory disease, and even with such signs there is little to distinguish EHV-1 respiratory disease from other viral and bacterial pathogens. Respiratory EHV infection frequently goes undetected. A common misconception is that monitoring for respiratory clinical signs provides a warning for impending abortion or EHM: most horses that abort or develop neurological disease after EHV-1 infection do not show signs of respiratory disease. If multiple horses are at-risk after an index case, monitoring rectal temperature may help identify potentially infected animals that might be at risk of EHM.

Gross pathology of abortion features (Figure 3):

- Rapid expulsion of fetus and placenta intact

- Fresh fetus
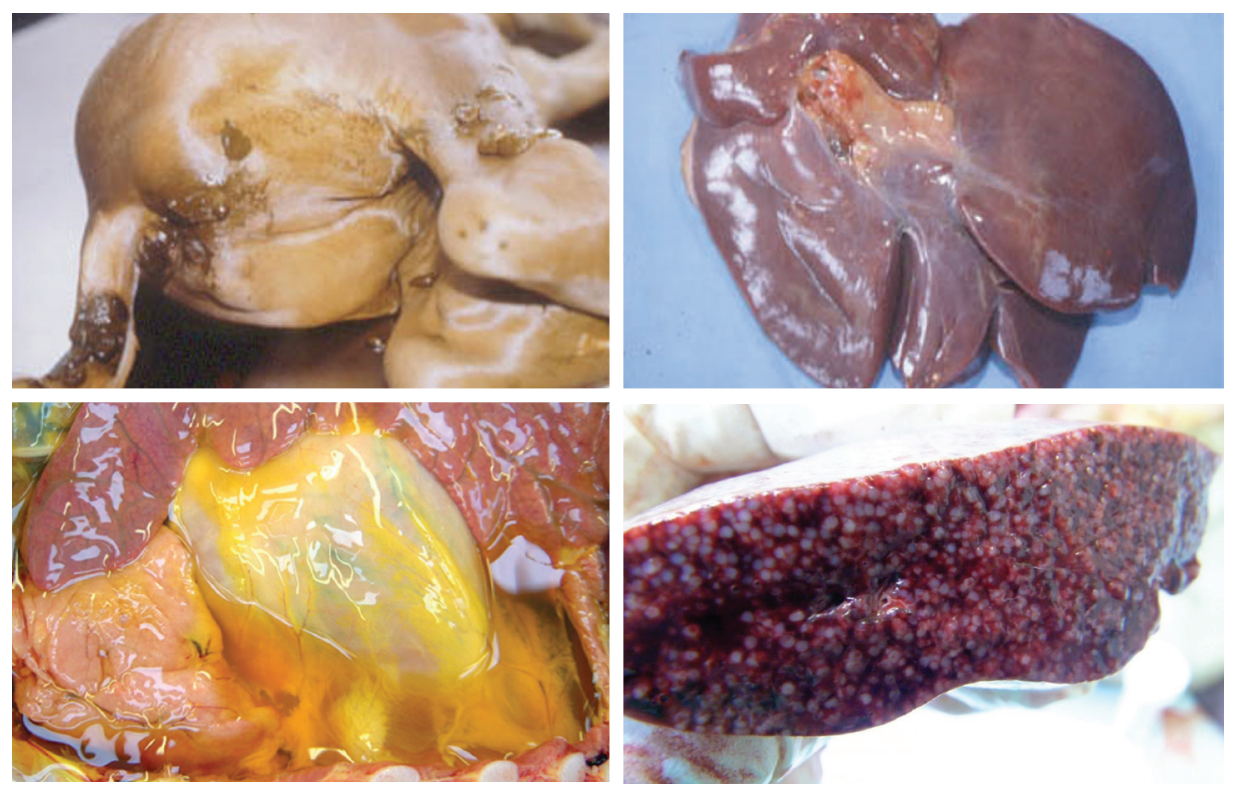

Figure 3. Typical gross findings in EHV abortion include meconium staining, blood-stained fluid pooling in body cavities, enlarged spotty liver and prominent splenic follicles. (Images courtesy of Prof Ken Smith, RVC)

- Meconium staining

- Blood stained fluid pooling in body cavities

- Pulmonary oedema

- Enlarged spotty liver

- Prominent splenic follicles. Pathology of EHM features:

- Vascular thrombosis, infarction and inflammation

- Ischaemic or haemorrhagic degeneration (myelopathy).

\section{Sampling to confirm the diagnosis}

Case selection is critical: all samples for direct demonstration of virus should be collected from early clinical cases (ideally $<5$ days from initial fever) whenever possible. This is best achieved by identifying in-contact cases with pyrexia that may as yet have not shown any other clinical signs, although samples from clinical cases may also be taken, especially if they appear to be the only horses affected. Proper selection of cases for sampling is particularly important in EHM cases, where clinical signs appear towards the end of viraemia when viral shedding is waning or may have ceased. If fresh fetal tissues are being sent, liaising with the laboratory for weekend and outof-hours testing is advised.

\section{Samples}

\section{Nasopharyngeal swab}

When swabbing to check for the presence of virus, a long, highly absorbent swab passed up the ventral meatus of the nasal passageways to the level of the medial canthus should be used (available from the AHT) to ensure adequate sampling of the nasopharyngeal mucosa; short bacteriology swabs are not appropriate. Swabs should be placed in viral transport medium (e.g. white-top tube from AHT). (The sample should be refrigerated and time minimised before arriving at the laboratory). Tests undertaken may include:

- Quantitative Polymerase Chain Reaction ( $q P C R)$ for detecting viral DNA is sensitive and allows estimation of the amount of virus ('viral load') in the sample (Daly and Doyle, 2003; Hussey et al, 2006;). Turn-around is short, with results generally being reported on the day of receipt.

- Virus Isolation (VI) is traditionally regarded as the 'gold standard' test but takes 5-7 days and is insensitive compared to qPCR. It is very useful for research into virus sequences and epidemiology to track outbreaks.

\section{Blood}

- qPCR may be used to detect viral DNA in buffy coat cells (mainly lymphocytes) from blood collected into EDTA. Turn-around is short, with results generally being reported on the day of receipt.

- Serology may be used to detect a rise in antibody induced by EHV-1 infection and thus indicate exposure to EHV-1. In the UK complement fixation (CF) test is the default serological test.

- IgM: detectable 4-5 days after infection, peaking at 20-30 days, returning to 


\section{Table 4. History and samples to collect in the face of suspected} EHV-1 abortion, weak neonatal foal or EHM

\begin{tabular}{|c|c|c|}
\hline $\begin{array}{l}\text { Observation / } \\
\text { Samples }\end{array}$ & Details/reasons/actions & Tests requested \\
\hline History & $\begin{array}{l}\text { Abortion > } 5 \text { months gestation } \\
\text { Sometimes a rapid delivery with the foetus } \\
\text { being expelled still contained within the } \\
\text { placenta ("red bag") } \\
\text { EHV-1 vaccination history (if known) } \\
\text { Absence of any other gross findings is } \\
\text { suggestive however other conditions can } \\
\text { occur concurrently with EHV }\end{array}$ & $\begin{array}{l}\text { Fetal and placental tis- } \\
\text { sue for PCR screening and } \\
\text { histopathology }\end{array}$ \\
\hline $\begin{array}{l}\text { Weak neonatal } \\
\text { foal }\end{array}$ & Anti-coagulated blood & $\begin{array}{l}\text { Haematology } \\
\text { (not specific for EHV) }\end{array}$ \\
\hline $\begin{array}{l}\text { Gross fetal } \\
\text { pathology }\end{array}$ & $\begin{array}{l}\text { Fresh fetus (limited autolysis) } \\
\text { Meconium staining }\end{array}$ & \\
\hline $\begin{array}{l}\text { Gross pathology } \\
\text { of fetal organs }\end{array}$ & $\begin{array}{l}\text { Copious, blood stained fluid in body } \\
\text { cavities } \\
\text { Pulmonary oedema } \\
\text { Enlarged spotty liver } \\
\text { Prominent splenic follicles }\end{array}$ & \\
\hline $\begin{array}{l}\text { Fetal liver, lung, } \\
\text { thymus (two } \\
\text { pooled samples) }\end{array}$ & $\begin{array}{l}\text { Place in one pot of neutral buffered formal } \\
\text { saline to detect viral antigen } \\
\text { Place in a second pot of virus transport } \\
\text { medium for virus isolation (AHT labs) }\end{array}$ & $\begin{array}{l}\text { Immunohistochemistry } \\
\text { Virus isolation }\end{array}$ \\
\hline $\begin{array}{l}\text { Deep nasopharyn- } \\
\text { geal swab }\end{array}$ & $\begin{array}{l}\text { To detect viral DNA/infectious virus } \\
\text { Place in viral transport medium with antibi- } \\
\text { otics (e.g. White top tube from AHT) } \\
\text { Refrigerate sample }\left(4^{\circ} \mathrm{C}\right) \\
\text { Transport to laboratory urgently }\end{array}$ & $\begin{array}{l}\text { Quantitative PCR* } \\
\text { Virus isolation }\end{array}$ \\
\hline $\begin{array}{l}\text { Single blood } \\
\text { sample }\end{array}$ & $\begin{array}{l}\text { Anti-coagulated (EDTA or LiHep) } \\
\text { To detect viral DNA in white blood cells } \\
\text { (buffy coat) }\end{array}$ & $\begin{array}{l}\text { *Quantitative PCR } \\
\text { Virus isolation }\end{array}$ \\
\hline $\begin{array}{l}\text { Paired blood } \\
\text { samples }\end{array}$ & $\begin{array}{l}\text { Clotted for antibody tests } \\
\text { At an interval of } 10-14 \text { days } \\
\text { - recent infection indicated with fourfold } \\
\text { or greater rise in antibody titre in absence } \\
\text { of recent vaccination } \\
\text { - not diagnostic for EHV abortion } \\
\text { - moderate to high antibody titres may be } \\
\text { found in EHM cases in absence of recent } \\
\text { vaccination }\end{array}$ & ${ }^{\star}$ Complement fixation test \\
\hline $\begin{array}{l}\text { Cerebrospinal fluid } \\
\text { (suspected EHM } \\
\text { only) }\end{array}$ & $\begin{array}{l}\text { Assess colour: xanthochromic (yellow } \\
\text { discolouration) } \\
\text { Indirect measures of EHV-1 infection. } \\
\text { Blood contamination during sampling may } \\
\text { make interpretation difficult }\end{array}$ & $\begin{array}{l}\text { Total protein } \\
\text { White blood cell count } \\
\text { Virus-specific antibodies }\end{array}$ \\
\hline
\end{tabular}

baseline between 60-80 days (Thomson et al, 1976). Measured by complement fixation (CF) test (Doll et al, 1953a; 1953b).

- IgG: detectable 8-10 days after infection, peaking at 30-40 days, persisting for many months ( $>9$ months). Measured by virus neutralisation (VN) or ELISA (the latter claimed to be able to differentiate between EHV-1 and EHV-4).

- Technique: take a baseline sample and repeat sample 10-14 days later (Thompson et al, 1976). Significant increase in CF (IgM) antibody level is usually defined as a four-fold or greater increase in titre, but can be stimulated by vaccination as well as infection.
- Interpretation: a high CF titre (IgM) in a single serum sample from a non-vaccinated horse provides good preliminary evidence of EHV-1 infection and is a valuable initial diagnostic test in suspected EHM cases.

- Note: previous vaccination and maternal antibodies confound the interpretation of serological investigations, particularly in bloodstock and foals.

- Haematology may be used to indicate the presence of infection; however, results are non-specific and difficult to interpret if only a single sample is taken. For the first 7-10 days after infection a transient leucopenia with lymphopenia is expected. Leucopenia is replaced by a leucocytosis with lymphocytosis up to 21 days after infection. In neonatal foals, a lymphocyte count of $<2 \times 10^{9} / 1$ is associated with a very poor prognosis and a strong clinical suspicion of neonatal EHV-1 infection (Perkins et al, 1999).

Tissue: e.g. fetal, placental or central nervous system (CNS) tissue (Smith et al, 2004)

- Histopathological examination of EHV-1 infected tissues typically reveals eosinophilic inclusion bodies, vasculitis and often thrombosis of CNS blood vessels (Whitwell et al 1992a; 1992b)

- Immunohistochemistry of fetal or placental tissues may be used to identify EHV-1 antigen.

\section{Cerebrospinal fluid (CSF) in EHM cases}

- Xanthochromic (yellow coloured) CSF see Figure 4)

- Total protein is typically increased without a concomitant increase in leucocytes

- Concurrent xanthochromia and elevated protein is highly suggestive, but not

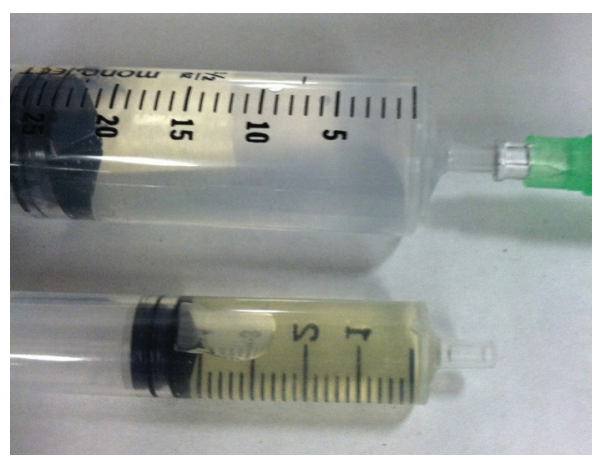

Figure 4. Normal (above) and xanthochromic (yellow, below) cerebrospinal fluid. 
diagnostic, of EHM in horses with supportive clinical signs

- Antibodies to EHV-1 in the CSF may be from leakage as a result of vasculitis, not from local production, so this does not definitively confirm EHM and may be the result of EHV-1 exposure.

\section{EHV-1 prevention resources}

Good resources to act as guides for the control of EHV-1 include the HBLB codes of practice https://codes.hblb.org.uk/index.php/page/32; and Equibiosafe App https://itunes.apple.com/ gb/app/equibiosafe/id1131137694), which is provided free to horse trainers, owners, breeders and veterinary surgeons in the UK by the Horserace Betting Levy Board and the National Trainers Federation, and the AAEP/USDA guide in USA https://aaep.org/guidelines/infectiousdisease-control/equine-herpesvirus-resources.

\section{Steps to prevent EHV-1}

abortion or manage an abortion outbreak

The following steps are in accordance with the HBLB Codes of Practice (https://codes.hblb. org.uk/index.php/page/32)

\section{Prevention of disease entry to premises} Transmission of EHV-1 onto a property cannot be prevented, because the majority of horses carry latent (and thus undetectable) EHV-1 that may reactivate unpredictably, often following unknown stress events. To reduce the risk of disease entry:

- New arrivals should ideally have been vaccinated in advance of relocation to their new premises, and should be kept isolated from other horses until sufficient time (usually 3 weeks) has passed for disease to become apparent.

- On studs, newly arrived and 'walk-in' mares should be separated from resident in-foal mares. Mares arriving at studs to foal should be transported at least 28 days before the foaling due date.

- Horses that have arrived from sales or markets are high-risk and should be subject to more stringent isolation and biosecurity measures.

- Young stock (less than 2 years old) are a major source of EHV-1 so should be separated from pregnant mares at all times.

- In yards with no pregnant mares, an isolation period of at least 21 days is advised, because viral shedding may occur after reactivation of the virus induced by the stress of moving.

- Minimising stress in resident horses, including transport, disruption of established social groups, and tapered weaning should assist in reducing the frequency of reactivation of the virus from the latent state.

\section{Limiting the spread and severity} of disease

Different age groups should not be mixed.

- Group size should be kept as small as practicable

- Pregnant mares should be separated from other horses and kept in small groups to minimise the risk of a large-scale outbreak

- Mares in their last trimester should ideally be housed and managed individually

- Isolation areas should be geographically separate and biosecurity rigorously maintained.

\section{In the event of a suspect case}

If a suspect case occurs the horse should be isolated immediately and appropriate samples taken. Isolation can be in a remote area of the existing premises or even some miles distant from these premises, if there is safe place for this to happen.

- Collect appropriate samples. The intact fetus and placenta should ideally be transported to a laboratory. If this is not possible then fresh liver, lung, thymus, spleen and multiple sites of the chorioallantois should be sent and kept cool in transit. In addition, samples of the same tissues plus kidney and adrenal gland fixed in formalin should be sent for histology. Swabs for culture of liver, lung, gastric contents, and the cervical pole of the chorioallantois may aid the diagnosis of causes other than EHV.

- Make telephone contact with a recognised laboratory to provide a comprehensive history and information on the premises, or ensure this is well documented with the submission forms.

- Photographic recording of an in-field abortion may help the pathologist reach a diagnosis, particularly if the clinician is not experienced in recording their findings and recognising abnormal features in an aborted fetus or placenta.

- Appropriate sampling kit including plain and formal saline pots, swabs etc. - see Box 1 . Abortion Kit List - should be available

- Packaging appropriate for the submission
Box 1. Abortion kit list

- Submission form

- Post-mortem form

- Laboratory postage labels (UN 3373)

- Pot(s) with lid(s) for fresh tissue samples

- Pot for fetal stomach contents

- Pot(s) with lid(s) containing formal saline for fixed samples

- Swabs with transport media for placenta, liver and/or lung

- Blood tube(s) for serological screening (first of two paired samples)

- Packaging materials compliant with UN No. 3373:

- Hard protective outer package

- Absorbent material (to soak up any spillage and provide padding)

- Inner waterproof packaging (bag) to prevent spillage if pots break/leak

- Packing tape

of diagnostic specimens (compliant with Un No. 3373) - see Box 1. Abortion Kit List.

- Any in-contacts should be isolated, handled either by dedicated personnel or last thing in the day, and monitored for clinical signs. Rectal temperatures should be taken twice daily. A full body shower and change of clothes should be undertaken by any person after handling in-contact animals, and vehicle movements restricted.

- Veterinary surgeons investigating potentially infectious cases should ideally wear personal protective clothing and gloves, which should be thoroughly disinfected and bagged on site before leaving. Disinfection of areas of the vehicle at risk of contamination, e.g. floor mat(s) ,should be considered. A full body shower and change of clothes should be undertaken as soon as practically possible assuming it can not be done on site.

- If the in-contact group is large and it is practical to do so, it should be subdivided further, ideally minimising stress by keeping the mares within sight and sound, but not direct contact, with each other.

- EHV-1 can survive for limited periods depending on the surface and prevailing weather conditions. One report states 3 weeks in vitro (Dayaram et al, 2017). All discharges and abortion products from affected horses should be cordoned off, then removed and the area disinfected with viricidal disinfectant (Tsujimure et al, 
2015) e.g. VirkonTM. Bedding should be removed and ideally incinerated or bagged and disposed of.

- Disinfect water troughs or cover water troughs in places where infected mares are resident, to avoid cross-contamination.

- Stop all movements on and off the premises.

- Isolate aborted mares for 28 days and do not mix with pregnant mares for 56 days, unless active laboratory surveillance allows this time frame to be shortened.

\section{Limiting the spread to other properties}

- Ensure there is effective communication between attending vets, premises' owners and other parties working with the affected premises - farriers, dentists etc.

- Warn of risks of disease transmission with personnel and fomites - easy and clear biosecurity measures should be implemented. https://www.bef. co.uk/Detail.aspx ? page $=$ Horse-Health Biosecurity

- Consider vaccinating horses in the region, but separate to the yard and not in-contact.

\section{Vaccination to prevent EHV abortion}

Vaccination of all horses on the yard is indicated to reduce viral shedding. There are two groups to consider:

Pregnant mares: vaccinate at 5, 7 and 9 months of pregnancy. Batching mares together for vaccination, by vaccinating within 2 weeks either side of optimal date, is considered by the group to be acceptable.

Other horses on the breeding premises (stallions, non-pregnant mares, youngstock): Primary course of V1 and V2 4 weeks apart followed by 6-monthly booster vaccination.

There is evidence that administering influenza and EHV-1 vaccination (using a vaccine not currently marketed) on the same day does not adversely affect the efficacy of either vaccine (Heldens et al, 2001).

\section{Steps to take to prevent EHM or respiratory disease}

The key to preventing respiratory or neurological disease from EHV is understanding latency of the virus. It is likely that the majority of horses contain latent EHV-1 within white blood cells and the trigeminal ganglion. Stress may trigger reactivation of latent virus, but stress is poorly defined and will be different for different horses (Figure 5). For example, taking one mare out of a group of pregnant mares will

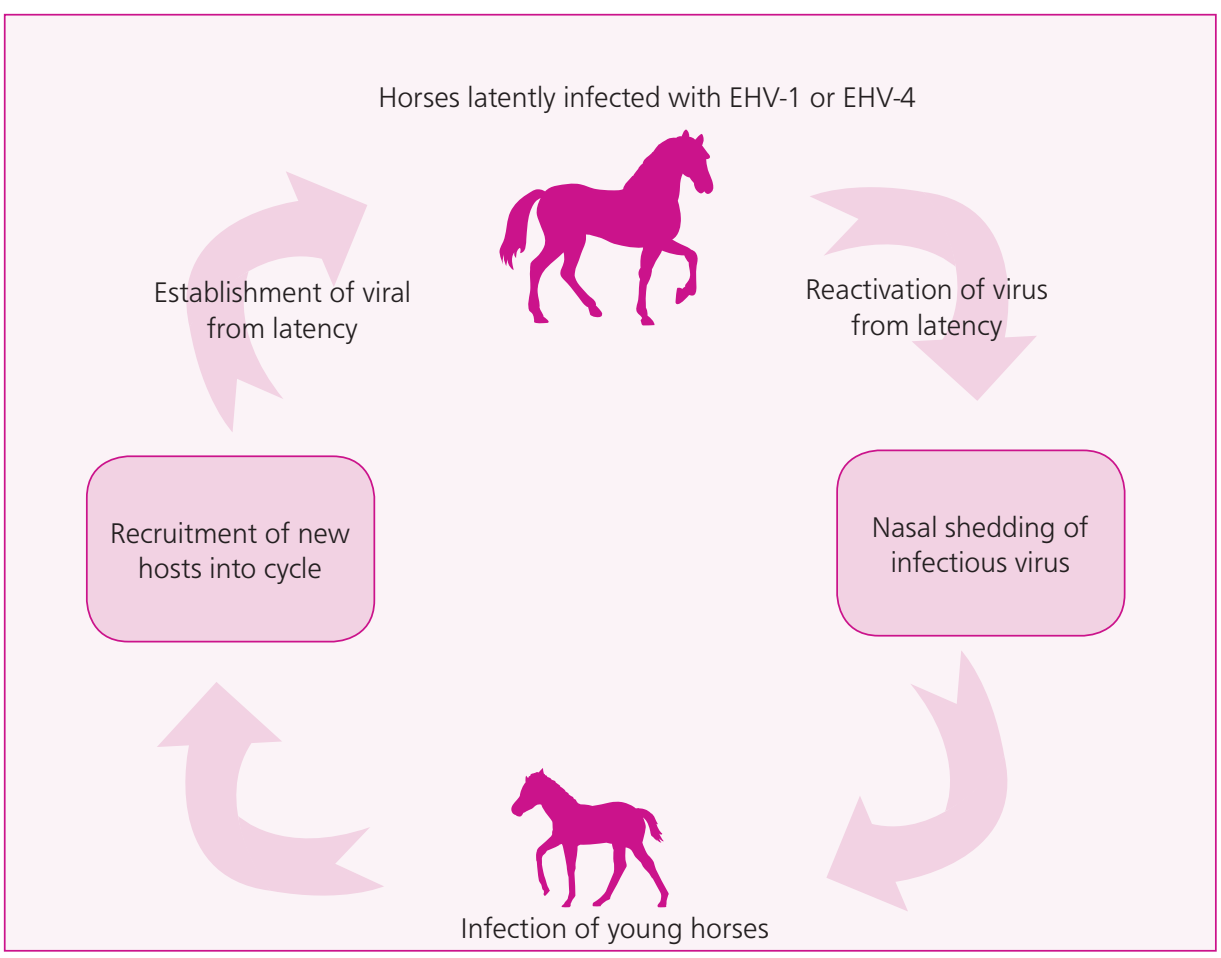

Figure 5. EHV-1 persists in the host and thus disseminates between the equine generations by establishing viral latency and subsequent reactivation (courtesy of Prof George Allen, Gluck Equine Research Centre).

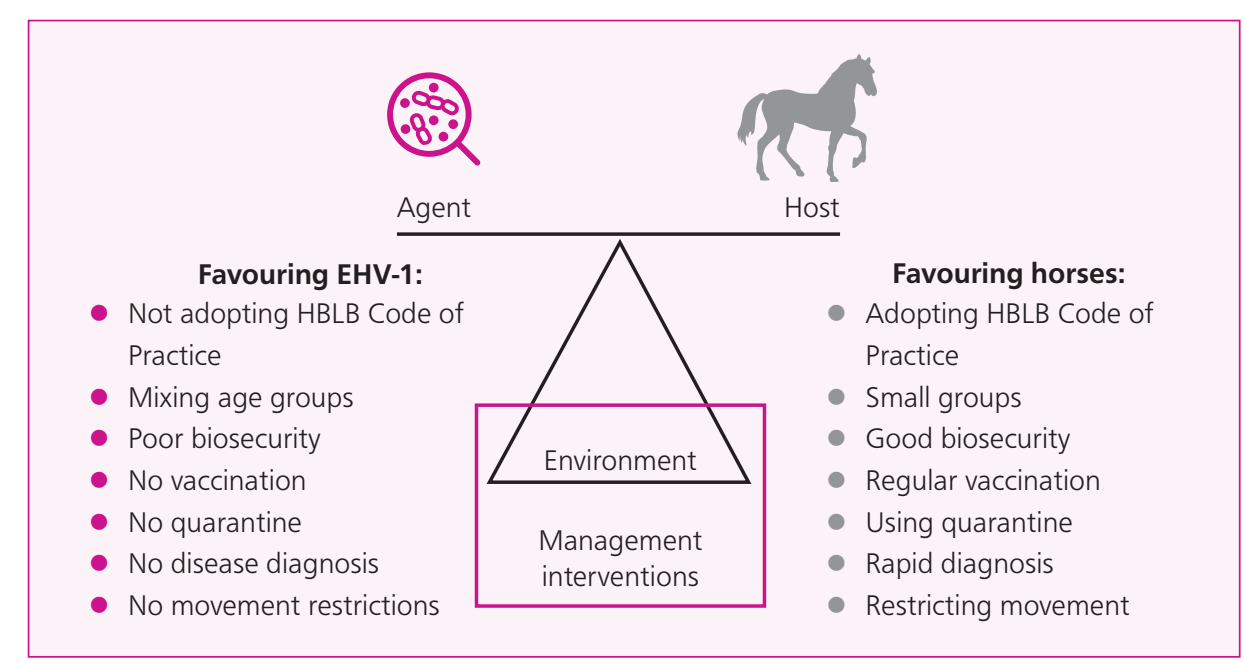

Figure 6. Factors favouring the host or the agent in EHV-1 infection.

mean the remaining mares will likely re-establish their hierarchy or 'pecking-order', leading to stress and possible EHV-1 reactivation.

Vaccination has little impact on EHV-1 latency and reactivation. Due to widespread latency, EHV-1 disease can only be managed and not eradicated. EHV-1 (represented by 'Agent' in Figure 6) can therefore be thought of as being in equilibrium with the horse (represented by 'Host' in Figure 3), with the environment and in particular management interventions acting as a pivot point that favours either the agent or the host. Management interventions such as adopting the HBLB Code of Practice, maintaining small groups, applying good biosecurity, quarantine, regular vaccination, rapid diagnoses and restricting movements, all benefit the horse population and reduce the risk and impact of EHV-1 infection. These measures do not eliminate this risk, hence EHV-1 related disease still occurs even in the very best managed systems. However, by not following these practices the risk of EHV-1 related disease with more extensive and severe outcomes increases. 


\section{Management and treatment of horses infected with EHV-1}

It is not feasible to prevent introduction of $\mathrm{EHV}-1$ or 4 onto a premises, therefore there is no point 'blacklisting' animals with previously confirmed infection. All new horses should be managed under the assumption that they are potentially incubating or actively shedding or may reactivate latent EHV-1 or -4 shortly after arrival. Thus, a quarantine period of at least 3 weeks, with daily monitoring of rectal temperature, is advised. If quarantine facilities are limited, then discussion with the owner in advance of new arrivals can help to identify and facilitate temporary but effective arrangements, including staff training.

\section{Management and treatment of horses with EHM}

The following interventions may help in the management of EHM (Pusterla and Hussey, 2014):

- Provide adequate bedding and bandaging to prevent trauma particularly to the lower limbs and head

- Maintain a quiet environment to prevent excitement

- Consider the use of slings (e.g. Anderson sling) for recumbent horses, although the prognosis in such cases is poor

- Place in-dwelling Foley catheter in horses with bladder paralysis, urinary retention and overflow incontinence

- Apply petroleum jelly around the perineum along with an extension line to direct urine away and prevent scalding

- Cystitis is a common complication and antimicrobial therapy is often indicated

- Evacuate faeces regularly if there is faecal incontinence/rectal impaction, to prevent rectal tears

- Provide intravenous or enteral fluids as necessary.

The following medications may also be used, although their justification is theoretical, as no studies have been performed to demonstrate efficacy in EHM:

- Non-steroidal anti-inflammatory drugs are used commonly as adjunctive therapy, although their capacity to affect the development of the lesions of EHM is unknown (e.g. flunixin $1 \mathrm{mg} / \mathrm{kg}$ IV or PO BID).

- Corticosteroids could aid in the control or prevention of the cellular response adjacent to infection of the CNS endothelial cells, thereby potentially reducing vasculitis, thrombosis and resultant neural injury.
However, they may also have a potentially deleterious immunospressive effect. Therefore reserving their use to recumbent cases or severe ataxia in which the prognosis is guarded for survival is sensible (Lunn et al, 2009) (e.g. sodium phosphate dexamethasone $0.1 \mathrm{mg} / \mathrm{kg}$ IV SID).

- Nucleoside analogues (Garre et al 2007a; 2007b).

- Acyclovir $10 \mathrm{mg} / \mathrm{kg}$ PO five times daily. Note poor bioavailability and questionable efficacy with EHV-1.

- Valacyclovir 20-40 mg/kg PO TID. Better bioavailability than acyclovir but more expensive (Garre et al, 2009a; 2009b; Maxwell et al, 2009; 2017). It potentially reduces severity of EHM if administered 2 days after challenge infection at onset of fever.

- Ganciclovir $2.5 \mathrm{mg} / \mathrm{kg}$ intravenously q8hours for first 24 hours then orally every 12 hours. In vitro this is the most potent drug in the class, but it is very expensive (Carmichael et al, 2013).

- Low molecular weight heparin may reduce thrombosis: $80 \mathrm{U} / \mathrm{kg}$ q24 hours (Walter et al, 2016; Stokol et al, 2018).

- Immunostimulants such as Parapoxovis in one study of natural EHV-1 exposure caused a reduction in clinical signs of respiratory disease (Ons et al, 2014). Their use has not been evaluated in the context of EHM outbreaks and it is not licensed for this purpose. Therefore the authors do not recommend this for the use in EHM cases.

- Aspirin has a theoretical indication for the prevention or propagation of thrombus formation - 5-20 mg/kg PO q12-48 hours. If ataxia is detected, the horse should be walked in a figure-of-eight twice daily to monitor recovery or progression of clinical signs. Some horses will show no noticeable premonitory signs, such as pyrexia, but present immediately with EHM. Severely EHM-affected horses may recover, but most are euthanased within 48 hours on welfare grounds due to secondary complications, for example bacterial pneumonia, bacterial cystitis and/or myopathy.

\section{EHV-1 vaccination:} when and why?

Epidemics of herpesvirus respiratory disease, abortion and /or paralysis were relatively common in the 1960s, 1970s and 80s, for example:

- Outbreaks in which abortions occurred in up to $70 \%$ of exposed unvaccinated pregnant mares (Mumford et al, 1987)

- Reports of concurrent outbreaks of abortion and neurological disease (Charlton et al, 1976; McCartan et al, 1995).

Less commonly there have been reports in vaccinated animals, for example in one outbreak of 61 clinically affected horses, 6/7 pregnant mares aborted and 8 horses developed EHM (Walter et al, 2013).

EHV-1 and 4 vaccination can lead to a reduction in infectious virus circulating in the population and has likely contributed, alongside the managemental preventative practices adopted over this time, to fewer outbreaks of disease being reported. There is also evidence of reduced respiratory disease and nasopharyngeal virus shedding and abortion in vaccinated animals (Heldens et al, 2001; Goodman et al, 2006). However, in vaccinated pregnant mares, cases of abortion still occur and vaccination is only one tool in the prevention of abortive disease.

In contrast, the efficacy of vaccination to prevent the development of EHM is unknown. The pathogenesis of EHM is poorly characterised, but it has been postulated that immune-mediated disease involving immune complexes plays some role (Edington et al, 1986). In addition, the case for vaccination is complicated by reports of increased risk of EHM: when horses had been vaccinated against EHV-1 in the preceding year (Henninger et al, 2007); and approximately 5 weeks before the outbreak (Traub-Dargatz et al, 2013). These findings may indirectly support the theory of immune-mediated involvement in the pathogenesis of EHM. Older horses (>15yrs old) are known to be at greater risk of EHM (Allen et al, 2008). When age was considered, recent vaccination ceased to be a risk factor in the Henninger et al (2007) study. The role of vaccination as a risk factor for EHM therefore remains uncertain. The current vaccines do not claim to protect against EHM and should only be offered as a means of reducing nasal shedding of virus from healthy horses and thus reducing environmental load of EHV-1 and -4.

Vaccinating horses in the face of an outbreak of EHM is contraindicated, for the above reasons, and also interferes with potential serological screening of in-contacts. That said, vaccination may be advisable for the horses outside the immediate geographical location of the outbreak, to reduce the long-term EHV-1 shedding and improve herd immunity - the increased owner awareness of EHV that accompanies these outbreaks may be used to encourage this. 


\section{EHV-1 and EHV-4 vaccination in competition horses}

There are currently no official requirements for vaccination against EHV-1 in the United Kingdom. In France, racing Thoroughbreds have to receive a primary course of three vaccinations followed by annual boosters, in line with their requirements for equine influenza. This is in conflict with the manufacturer's recommendations and current evidence. For effective protection, antibody titres are likely to require boosting at 6-month intervals. Therefore, horses should be vaccinated every 6 months in line with datasheet recommendations.

In Thoroughbred racing in the UK, vaccination against EHV-1 is not uncommon to protect against respiratory disease and the associated lower airway inflammation. Some trainers also believe that vaccination can act as a general immunostimulant; this may be related to the non-specific effects of adjuvant within the vaccine formulation, although there is currently no scientific evidence to support this concept.

In other affiliated sport horse disciplines there is limited EHV-1 vaccination uptake. Postulated reasons are cost, little to no recognition of the risks posed by EHV-1 infection, lack of compulsory vaccination by regulatory bodies and a reluctance to engage with the subject. In contrast, there are robust arguments in favour of EHV-1 vaccination amongst these elite athletic horses, many of which travel nationally and internationally on a regular basis, mixing with other horses from many different countries. Such arguments including protection against respiratory disease and thus loss of work and performance, as well as contribution to protection of the national equine herd. Improved methods and efforts to communicate this message are required. The development of a bivalent vaccine incorporating influenza virus and EHV-1 may facilitate uptake by horseowners and thus improve protection nationally (Gildea et al, 2016).

It is recommended that the following groups of horses be re-vaccinated against EHV-1 at 6-month intervals:

- Horses less than 5 years of age (but $>6$ months old)

- Horses that may come into contact with pregnant mares

- Horses housed at facilities with frequent equine movements on and off the premises

- Performance or show horses in high-risk areas where horses mingle in close proximity, for example racetracks or show jumping, eventing and dressage competitions.

Vaccination should be at suitable time points in the horses' competition schedules, to avoid any impact of vaccine reactions, to allow enough time to comply with requirements of different organisations and to allow enough time ( $>7$ days) for an immune response to be generated. In the authors' opinion, horses should be rested for 2-3 days after vaccination.

\section{Future directions in controlling EHV-1}

Evidence suggests improved protection against EHV-1 will likely require both neutralising antibody and cell-mediated cytotoxic T-lymphocyte (CTL) responses. Mucosal antibodies can play a role in preventing infection of the respiratory tract and in limiting virus shedding. Cytotoxic lymphocytes that lyse virus-infected cells appear to be required to prevent abortion. Control of cell-associated viremia is thought to be critical for the prevention of EHV-1 abortion and, presumably, neurological disease. Serum antibody titres correlate with virus shedding rather than the duration of cell-associated viremia or the outcome of pregnancy following challenge infection (Kydd et al, 2006).

\section{Vaccine technologies \\ Killed vaccines}

Chemically inactivated virus can be whole or split using detergents, for example Equip EHV1,4 (Zoetis). Commercial preparations include an adjuvant to increase the amplitude of the immune response (e.g. aluminium hydroxide, or carbomer). It is thought to require both EHV-1 and -4 antigens to cross-protect. Vaccines can stimulate both virus neutralising and complement fixation antibodies, the levels of which have been linked to the reduction of virus shedding. Some of these vaccines have a licensed claim for reduction in abortion but there is no licence for protection against neurological disease.

\section{Vectored vaccines}

These are constructed by inserting genes of interest into live viruses such as poxviruses, adenoviruses or herpesviruses that are used as a vaccine delivery tool, e.g. Canarypox virus (Merial) (Minke et al, 2006) or modified Vaccinia virus Ankara (non-replicating chicken adapted) (Huemer et al, 2000), that can bypass maternal antibodies. These are cheap to produce once established. These allow sim- ple DIVA strategies (differentiating infected from vaccinated animals). The identity of the immunodominant protective antigens of EHV-1 to insert into the genome has not yet been determined for all equine genotypes.

\section{Subunit vaccines}

These contain one or more pure or semi-pure antigens. They are safe to use, but are expensive to produce commercially. The immunodominant protective antigens of EHV-1 have yet to be identified for use in subunit vaccines.

\section{Live attenuated vaccines}

Historically these are based on highly passaged virus isolates that have lost their virulence yet still induce an immune response, e.g. Rhinomune (RacH strain). They closely mimic natural infection with the full 'antigenic breadth' Modern molecular biology techniques allow rational attenuation by specific modification of the virus genome. Live attenuated vaccines against a number of different infectious diseases are known to stimulate both antibody and Tlymphocyte responses in a number of different animal species. For safety, the vaccine must be incapable of reverting to a more virulent form. These do provide the opportunity for DIVA.

\section{Conclusions}

Understanding the biology of EHV-1 and -4 helps to construct strategies to reduce the incidence of disease, and central to this should be the recommendation to vaccinate at herd level. Ideally all horses on a yard would be vaccinated, with coverage reaching $70 \%$ of the national herd. Vaccination decreases the amount and duration of nasopharyngeal shedding of the virus, and therefore environmental contagion. Yard vaccination in the face of an outbreak is contraindicated, as the state of infection/immune response of the individuals will be unknown. Vaccination of closely associated horses (e.g. geographically), but on separate premises to the original outbreak, is potentially beneficial and should be judged on an individual basis in consultation with the testing laboratory and/or epidemiological input. Vaccination remains a valuable tool used appropriately to reduce environmental contagion and reduce disease incidence, when integrated into strict biosecurity and hygiene measures; however, currently the lack of a vaccine stimulating an antibody response that can be differentiated from natural infection (DIVA vaccine) makes it difficult to screen horses serologically once they have been vaccinated. 


\section{References}

Allen GP. Respiratory infections by equine herpesvirus types 1 and 4. In: Leukeux P (ed). Equine Respiratory Diseases. Ithaca (NY): International Veterinary Information Services; 2002

Allen GP. Risk factors for development of neurologic disease after experimental exposure to equine herpesvirus- 1 in horses. Am J Vet Res. 2008;69(12):1595-600. doi: 10.2460/ ajvr.69.12.1595

Allen GP, Kydd JH, Slater JD, Smith KC. Advances in the understanding of the pathogenesis, epidemiology and immunological control of equine herpesvirus abortion. In: Mumford JA, Wade JF (eds). Equine Infectious Diseases VIII. Newmarket: R\&W Publications; 1999. 129-66

Brosnahan MM, Al Abri MA, Brooks SA, Antczak DE Osterrieder N5. Genome-wide association study of equine herpesvirus type 1-induced myeloencephalopathy identifies a significant single nucleotide polymorphism in a platelet-related gene. Vet J. 2019;245:49-54. doi: 10.1016/j. tvjl.2018.12.013

Burgess BA, Tokateloff N, Manning S, et al. Nasal shedding of equine herpesvirus-1 from horses in an outbreak of equine herpes myeloencephalopathy in Western Canada. J Vet Intern Med. 2012;26(2):384-92. doi: 10.1111/j.19391676.2012.00885.x

Carmichael RJ, Whitfield C, Maxwell LK. Pharmacokinetics of ganciclovir and valganciclovir in the adult horse. J Vet Pharmacol Ther. 2013;36(5):441-9. doi: 10.1111/jvp.12029

Daly P, Doyle S. The development of a competitive PCRELISA for the detection of equine herpesvirus-1. J Virol Methods. 2003;107(2):237-44

Dayaram A, Franz M, Schattschneider A et al. Long term stability and infectivity of herpesviruses in water. Sci Rep. 2017;7:46559. doi: 10.1038/srep46559.

Doll ER, Wallace ME, Bryans JT, Richards MG. Complement-fixation antibody response following administration of equine virus abortion vaccine. Am J Vet Res. 1953;14(50):46-8

Doll ER, McCollum WH, Wallace ME, Bryans JT, Richards MG. Complement-fixation reactions in equine virus abortion. Am J Vet Res. 1953;14(50):40-5

Edington N, Bridges CG, Patel JR. Endothelial cell infection and thrombosis in paralysis caused by equid herpesvirus-1: equine stroke. Arch Virol. 1986; 90(1-2):111-2

Garré B, van der Meulen K, Nugent J, et al. In vitro susceptibility of six isolates of equine herpesvirus 1 to acyclovir, ganciclovir, cidofovir, adefovir, PMEDAP and foscarnet. Vet Microbiol. 2007a:122(1-2):43-51

Garré B, Shebany K, Gryspeerdt , et al. Pharmacokinetics of acyclovir after intravenous infusion of acyclovir and after oral administration of acyclovir and its prodrug valacyclovir in healthy adult horses. Antimicrob Agents Chemother. 2007b;51(12):4308-14

Garré B, Gryspeerdt A, Croubels S, De Backer P, Nauwynck $\mathrm{H}$. Evaluation of orally administered valacyclovir in experimentally EHV1-infected ponies. Vet Microbiol.
2009;135(3-4):214-221. doi: 10.1016/j.vetmic.2008.09.062 Garré B, Baert K, Nauwynck H, Deprez P, De Backer P, Croubels S. Multiple oral dosing of valacyclovir in horses and ponies. J Vet Pharmacol Ther. 2009;32(3):207-12. doi: 10.1111/j.1365-2885.2008.01025.x

Gildea S, Sanchez Higgins, MJ, Johnson G, Walsh C, Cullinane A. Concurrent vaccination against equine influenza and equine herpesvirus - a practical approach. Influenza Other Respir Viruses. 2016;10(5):433-7. doi: 10.1111/ irv.12396

Goehring LS, Landolt GA, Morley PS. Detection and management of an outbreak of equine herpesvirus type 1 infection and associated neurological disease in a veterinary teaching hospital. J Vet Intern Med. 2010;24(5):1176-83. doi: 10.1111/j.1939-1676.2010.0558.x

Goodman LB, Wagner B, Flaminio MJ et al. Comparison of the efficacy of inactivated combination and modified-live virus vaccines against challenge infection with neuropathogenic equine herpesvirus type 1 (EHV-1).Vaccine. 2006;24(17):3636-45

Heldens JG, Kersten AJ, Weststrate MW, van Den Hoven $\mathrm{R}$, Duration of immunity induced by an adjuvanted and inactivated equine influenza, tetanus and equine herpes 1 and 4 combination vaccine. Vet Q. 2001;23(4):210-7

Henninger RW, Reed SM, Saville WJ et al. Outbreak of neurologic disease caused by equine herpesvirus- 1 at a university equestrian center. J Vet Intern Med. 2007:21(1):157-65

Hussey SB, Clark R, Lunn KF et al. Detection and quantification of equine herpesvirus-1 viremia and nasal shedding by real-time polymerase chain reaction. J Vet Diagn Invest. 2006;18(4):335-42

Horserace Betting Levy Board (HBLB) Codes of Practice 2019. http://codes.hblb.org.uk/ (Accessed: 14 April 2019)

Kydd JH, Townsend HG, Hannant D. The equine immune response to equine herpesvirus-1: the virus and its vaccines. Vet Immunol Immunopathol. 2006;111(1-2):15-30

Lunn DP, Davis-Poynter N, Flaminio MJ et al. Equine herpesvirus- 1 consensus statement. J Vet Intern Med. 2009:23(3):450-61 doi: 10.1111/j.1939-1676.2009.0304x

Ma, G., Azab, W., Osterrieder, N. 2013 Equine herpesviruses type 1 (EHV-1) and 4 (EHV-4): masters of co-evolution and a constant threat to equids and beyond. Vet Microbiol. 2013;167(1-2):123-34. doi: 10.1016/j. vetmic.2013.06.018

Maxwell LK, Bentz BG, Gilliam LL. et al. Efficacy of valacyclovir against disease following EHV-1 challenge. Proc Am Coll Vet Intern Med. 2009;176

Maxwell LK, Bentz BG, Gilliam LL et al. Efficacy of the early administration of valacyclovir hydrochloride for the treatment of neuropathogenic equine herpesvirus type- 1 infection in horses. Am J Vet Res. 2017 Oct:78(10):112639. doi: 10.2460/ajvr.78.10.1126

McCartan CG, Russell MM, Wood JL Mumford JA. Clinical serological and virological characteristics of an outbreak of paresis and neonatal foal disease due to equine herpes- virus-1 on a stud farm. Vet Rec. 1995;136(1): 7-12

Mumford JA, Rossdale PD, Jessett DM, Gann SJ, Ousey J, Cook RF. Serological and virological investigations of an equid herpesvirus 1 (EHV-1) abortion storm on a stud farm in 1995. J Reprod Fertil Suppl. 1987;35:509-18 Ons E, Van Brussel L, Lane S3 et al. Efficacy of a Parapoxvirus ovis-based immunomodulator against equine herpesvirus type 1 and Streptococcus equi equi infections in horses. Vet Microbiol. 2014;173(3-4):232-40. doi 10.1016/j.vetmic.2014.07.015

Perkins G, Ainsworth DM, Erb HN, Del Piero F, Miller M. Wilkins PA, Plamer J, Frazer M.Clinical, haematologica and biochemical findings in foals with neonatal Equine Herpesvirus-1 infection compared with septic and premature foals. Equine Vet J. 1999; 31(5):422-26

Pusterla N, Hussey G. Equine herpesvirus 1 myeloencephalopathy. Vet Clin North Am Equine Pract. 2014;30(3):489 506. doi: 10.1016/j.cveq.2014.08.006

Stokol T, Serpa PBS, Brooks MB, Divers T, Ness S. Subcutaneous administration of low-molecular-weight heparin to horses inhibits ex vivo equine herpesvirus type 1-induced platelet activation. Front Vet Sci. 2018;5:106. doi: 10.3389/ fvets.2018.00106

Smith KC, Whitwell KE, Blunden AS et al. Equine herpesvirus-1 abortion: atypical cases with lesions largely or wholly restricted to the placenta. Equine Vet J. 2004;36(1):79-82

Thomson GR, Mumford JA, Campbell J, Griffiths L, Clapham P. Serological detection of equid herpesvirus 1 infections of the respiratory tract. Equine Vet J. 1976;8(2):58-65

Traub-Dargatz JL, Pelzel-McCluskey AM, Creekmore LH et al. Case-control study of a multi-state equine herpesvirus myeloencephalopathy outbreak. J Vet Intern Med. 2013;27(2):339-46. doi: 10.1111/jvim.12051

Tsujimura K, Murase H, Bannai H, Nemoto M, Yamanaka T, Kondo T. Efficacy of five commercial disinfectants and one anionic surfactant against equine herpesvirus type 1. J Vet Med Sci. 2015;77(11):1545-8. doi: 10.1292/ jvms.15-0030

Whitwell KE, Blunden AS. Pathological findings in horses dying during an outbreak of the paralytic form of Equid herpesvirus type $1(\mathrm{EHV}-1)$ infection. Equine Vet 1992;24(1):13-19

Whitwell KE, Gower SM, Smith KC. An immunoperoxidase method applied to the diagnosis of equine herpesvirus abortion, using conventional and rapid microwave tech niques. Equine Vet J. 1992;24(1):10-12

Walter I, Seeh C, Fey K, Bleul U, Osterrieder N. Clinical observations and management of a severe equine herpesvirus type 1 outbreak with abortion and encephalomyelitis. Acta Vet Scand. 2013;55:19. doi: 10.1186/17510147-55-19

Walter J, Seeh C, Fey K, Bleul U, Osterrieder N. Prevention of equine herpesvirus myeloencephalopathy - is heparin a novel option? Tierarztl Prax Ausg G Grosstiere Nutztiere. 2016;44(5):313-17

\section{Keep up to date!}

\section{Subscribe to Equine the practical peer- reviewed CPD journal for the equine vet}

www.magsubscriptions.com/equine-vet

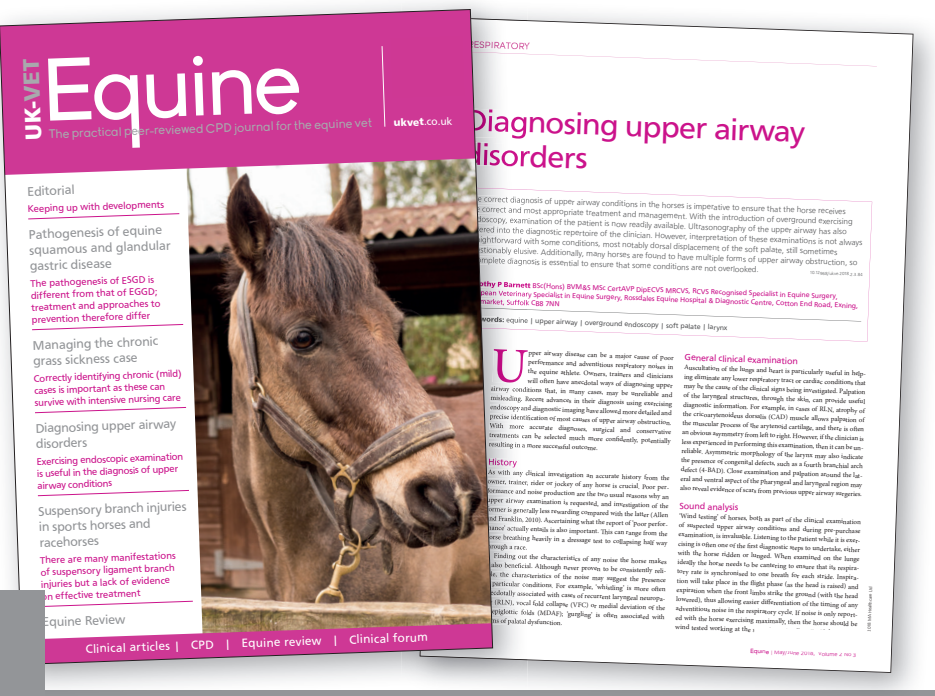

